\title{
e-WOM \& Purchase Intention towards Mobile Data Packages among Facebook users: The Mediating Effect of Brand Image
}

\author{
Christopher Wijeyakulasuriya \\ BIMA Lanka (Pvt) Ltd \\ christopher.wijeyakulasuriya@gmail.com \\ W.M.C.B. Wanninayake \\ Professor, University of Kelaniya, Sri Lanka \\ bandara@kln.ac.lk \\ D.A.T. Kumari \\ Senior Lecturer, Wayamba University of Sri Lanka \\ datkumari@gmail.com
}

DOI: http://doi.org/10.4038/sljmuok.v7i3.81

\section{ABSTRACT}

Facebook is undoubtedly the leading social networking service in Sri Lanka, which comprises approximately 7.9 million users by creating a massive platform to advertise and brand engagement. Therefore, it has become an essential tool for eWOM, which is crucial for Marketers to understand to leverage on social media. The Mobile Telecommunication industry is a competitive and technologically advanced sector in Sri Lanka, sized at $30.41 \mathrm{Mn}$ mobile connections rapidly ignite Social Networking Sites based interactions; hence, eWOM behaviour is pivotal to examine as a digital communicational tool and a reality. Accordingly, the purpose of this paper is to investigate the impact of eWOM on Purchase Intention as millions of consumers are now exposed to digital platforms and how impactful amidst the brand image among the Facebook users of Sri Lanka. Even though many scholars studied this issue in different contexts and very little research was done in Sri Lanka. The significance of this research instrumentalized to fill this gap and open a scholarly discussion. A survey conducted for data collection was instrumentalized via a 5-point Likert scale questionnaire among 267 respondents. The findings revealed a positive relationship between eWOM and Purchase Intention for Mobile data packages in the context of Sri Lankan Facebook users \& it was positively strengthened by Brand Image. Furthermore, this outcome could be used as base research to study eWOM on other platforms and give new knowledge to the academic $\&$ business world.

Keywords: Brand Image, Electronic-Word-Of-Mouth, E-wom, Facebook, Mobile Data, Purchase Intention, Sri Lanka, Telecommunication Industry

ORCID of authors: Christopher Wijeyakulasuriya - $\quad$ (D) https://orcid.org/0000-0001-5376-0036

W.M.C.B. Wanninayake - (D) https://orcid.org/0000-0002-5202-4077

D.A.T. Kumari - (DD https://orcid.org/0000-0001-9254-6868

Copyright: This is an open access article distributed under the Creative Commons Attribution License 4.0, which permits unrestricted use, distribution, and reproduction in any medium, provided the original work is properly cited. 


\section{INTRODUCTION}

Sri Lankan Mobile Telecommunication industry is one of the most competitive and technologically advanced industries in Sri Lanka, dominated by five mobile telecommunication players (NDB Securities, 2016). Thus, the country's total internet connection, including mobile and fixed connections, grew by 30.7 percent during 2020 (Central Bank Report, 2020). Furthermore, the Internet has become a factor that boosts web 2.0 tools such as online discussion forums, consumer review sites, and social network sites to exchange product information (Lee, Park, and Han, 2008). This mobile industry propelled Social Networking Sites (from now on referred to as SNS) based interactions, rocketed by engaging tens of millions of internet users (Richard \& Guppy, 2014). Facebook, Twitter, LinkedIn are the most famous SNS in the country (Hootsuite, 2021) \& consists of 7.9 million Facebook users (Facebook, 2021) \& ranked third highest user based SNS on the island (Alexa, 2021). Thus, Facebook has become one of the most penetrated Web 2.0 tools in Sri Lanka. Hence it is pivotal to study SNS behaviour in the Telecommunication industry further.

Word of Mouth (from now on referred to as WOM), defined as an oral form of non-commercial interpersonal communication among acquaintances (Arndt, 1967) and referred to as an informal communication between parties regarding the assessment of goods and services (Anderson,1998). Furthermore, WOM was identified as more influential than communication modes such as editorial or advertisements (Bickart and Schindler, 2001) because it was perceived to provide information relatively more reliable (Gruen et al., 2006). With the advancement of Internet-Technologies and increasing Internet usage, users are getting more information from the Internet. Thus, electronic word-of-mouth (referred to as eWOM) has resulted (Jalilvand, Esfahani \& Samiei, 2010) as an evolution of traditional WOM. Thus, eWOM excels with the web 2.0 tools which consist of SNS such as Facebook.

eWOM has emerged during the last decade and is now in the research field (Chan \& Ngai, 2011) and defined as an informal, person-to-person communication between a perceived non-commercial communicator and receiver regarding a Brand, Product, or Product organization, or a Service (Harrisonwalker, 2001). Further argues that the Internet enables customers to make opinions and share experiences with others and engage in WOM (Hennign-Thurau et al., 2004). eWOM is more innovative and adaptive than traditional WOM, and people are more influenced by information elicited from the Internet (Andreessen \& Streukens, 2009). Increased usage of the Internet could result from the effects of eWOM on Facebook, the leading SNS. Thus, vital to study this impact, as mentioned in DEI Worldwide (2008), as $70 \%$ of consumers reach SNS to peruse product information \& $49 \%$ of them complete the purchase decision based on that information. Further, Facebook users have admitted that they trust the platform and are more willing to share information (Dwyer, Hiltz \& Passerini, 2007). On the other hand, negative comments on such platforms badly impact businesses (Llonch et al., 2015). 
eWOM lets people think about the Brand \& create a 'Brand Image' in their mind (Yoo \& Donthu, 2001). The research was done on mobile users in Rawalpindi \& Islamabad, and it showed Brand Image (BI) mediated the relationship between Purchase Intention as well as clearly showed a positive relation with eWOM and Purchase Intention (Tariq et al., 2017) \& further justified in another research as BI plays a mediator role between eWOM and Purchase Intention (Jalilvand \& Samiei, 2012). Therefore, it is imperative to study how eWOM resulted in Purchase Intentions of different industries. Especially the impact of eWOM in the context of Sri Lankan mobile telecommunication industry constructs a larger landscape for more mobile data users and more potential Facebook users. This segment can generate eWOM, which could positively or negatively impact Purchase Intention for mobile data packages, which is a significant portion of revenue for any telecom company. Further justified in another research, Brand Image plays a mediator role between eWOM and Purchase Intention (Jalilvand \& Samiei, 2012). Therefore, the outcome of this study aimed to understand how the eWOM impacts Purchase Intention while moderated by Brand Image for mobile data packages in Sri Lankan Context with a particular reference given to the Facebook users \& this provides the implications to decision-makers. This paper outlines background study followed by literature review, conceptual framework \& methodology. Finally, it will be discussed on the data analysis and discussion on the research outcomes.

\section{LITERATURE REVIEW}

Accordingly, to Stigliz (2002), the Signaling Theory brings an Economic Perspective to the electronicword-of-mouth (eWOM) as a broader topic, Information Adoption Model explained by Sussman \& Siegal (2003) points puts as information: augment quality and source credibility (is essential to eWOM) \& Social Exchange Theory explained by Homans (1958) denotes how human exchange tangibles or intangibles as social rewards or punishments. Though these theories do not specifically discuss the Facebook platform behavior, human behavior is similar at larger scales beyond boundaries; hence based on these theories as a foundation, the author further explains in below the Independent Variable: eWOM, Dependent Variable: Purchase Intention and Mediating Variable: Brand Image in the below paragraphs.

\section{1. eWOM}

eWOM is any statement (positive or negative) made by prospective, actual, or ex-customers about a product available to many people/organizations Online (Henning-Thurau et al., 2004). Many customers employ Web 2.0 tools (e.g., SNS like Facebook) to interexchange product information (Cheung et al., 2008). eWOM holds exceptional Scalability, Speed of Diffusion (Cheung \& Thadani, 2010) \& it is asynchronous or multi-exchangeable (Hung \& Li, 2007). Thus, electronic Word of Mouth is vital to further research $\&$ analysis on different industries at a Market level to study implications like product sales or Individual level (Lee \& Lee, 2009), to study receiver's attitude \& purchase intension (Park \& 
Lee, 2008). This study can be further narrowed to study the Individual level of eWOM (Lee \& Lee,2009). Further, eWOM critically impacts consumers' product reviews and their purchase intention. Some sources for electronic word-of-mouth are virtual communities, newsgroups, websites, fan clubs, blogs, e-mail, etc. (Torlak et al., 2014).

Litvin et al. (2008) explained in the topology of eWOM channels, as Facebook-type SNS falls into many-to-many \& asynchronous scope with positives \& negatives according to research done by Jalilvand, Esfahani \& Samiei (2010) as depicted in Table 1 below:

Table 1: Positive \& Negative Factors of eWOM.

\begin{tabular}{|l|l|}
\hline \multicolumn{1}{|c|}{ Positive factors of eWOM } & \multicolumn{1}{|c|}{ Negative factors of eWOM } \\
\hline - Possible to get information from many (in dispersed & - Anonymity of communicators \\
geographies) & - Misleading \& out-of-context messaging \\
- Online opinions trustworthy & \\
- Low cost of access info & \\
- Broader scope & \\
\hline
\end{tabular}

Source: Authors compiled based on Jalilvand, Esfahani \& Samiei (2010)

In contrast to WOM, eWOM communications are identified with unprecedented scalability and speed of diffusion and are more persistent $\&$ accessible (Cheung \& Thadani, 2010), which is a more multiway exchange in asynchronous mode (Hung and Li, 2007). In addition, eWOM is more measurable (Lee, Park \& Hen, 2008). Research conducted by Cheung \& Thadani (2010) based on published journals $\&$ articles on eWOM from 2001 to 2010 period was derived outputs as most of the researchers examined at market level variables, how effects on product sales \& early $30 \%$ were discussed about the eWOM impact, Market \& Strategy at an average of $12 \%$ and surprisingly only $1 \%$ on Social Network aspects. There are 7.9 million are Facebook users (\& 92\% of them are active users (Hootsuite, 2018). Top of this, $86 \%$ of mobile subscribers access the Internet via mobile, and $23 \%$ of mobile data usage comes from social media consumption, excelled with $28 \%$ smartphone penetration mentioned in Nielsen report Sri Lanka Q4 2017 Dashboard (2018).

\subsection{Purchase Intention}

Purchase Intention hereinafter referred to as PI, described as transaction behaviour shown by customers at pre-\& post evaluation of goods \& services (Schiffman \& Kanuk, 2010). The likelihood behaviour of purchasing is also explained as purchase intention (Alford \& Biswas, 2000). Purchasing intention of customers can be varied in the different socio-economic contexts (Chovancova, Asamoah, \& Wanninayake, 2012). Further, PI of customers in different cultures is reflected in their shopping patterns (Wanninayake \& Chovancova, 2012). However, in on the online landscape, PI is defined as the extent of a consumer's Intention to buy online (Chu \& His-peng, 2007). This Intention can be changed by price or perceived quality or value, further affected by motivations derived internally or externally (Gogoi, 2013). The quality of online-reviews an eWOM component (Torlak et al., 2014) identified as positively 
impact on PI, in addition, studied that more intentions evolved when reviews increased, more than that identified in the research conducted that low involvement customers look for quantity of reviews, in contrast, the high involvement customers affected by the high quality of reviews. These findings clearly show different implications of reviews on purchase intentions (Park, Lee \& Han,2007). Further, the factors such as PI, attitude, information adoption, and trust are commonly investigated concerning the receiver's psychological state. Among the rest, PI has been widely studied in the scope of eWOM response (Cheung \& Thadani, 2010). More narrowing to SNS, the Facebook's like button, checked -in location, and share button applications have been identified positively impacting purchase intention (Richard \& Guppy, 2014); further, Facebook \& Twitter directly influence on purchase intension as people trust people as mentioned by Patel (2015) as summarized by Tariq et al., (2017). Purchase Intention for Mobile Broadband packages was further studied as there are $30.41 \mathrm{Mn}$ mobile connections which are $141.7 \%$ of the national population, as mentioned in Hootsuite (2021) in their report on the digital landscape. Thus, it is vital to further study the Purchase Intention on mobile data packages due to this growth which has implications on the industry's profitability and expansion of eWOM due to the high data consumption via this vast number of mobile connection users.

\subsection{Brand Image}

Brand Image hereinafter BI, defined as the consumer's impression \& feelings towards the Brand (Roy $\&$ Banerjee, 2007) \& the sum of connotations accumulated by perception regarding the Product formed in consumers' minds (Keller,1993). Further argued that BI is an essential factor in consumer buying behaviour (Burmann et al., 2008), as well as BI, is vital to long term cash flow \& sustainable competitive advantage of the companies. However, Wanninayake \& Chovancová, (2012) argue that BI can be damaged by the WOM of customers who are facing to post purchase dissonance. In addition to that eWOM let people think about the Brand \& create a 'Brand Image' on the mind (Yoo \& Donthu, 2001). At research done on mobile users in Rawalpindi \& Islamabad, it showed BI mediates the relationship between brand awareness and purchase intention as well as clearly showed a positive relation with eWOM and Purchase Intention (Kumari 2013; 2017;2020; Tariq et al., 2017) and further justified in another research as BI plays a mediator role between eWOM and Purchase Intention (Jalilvand \& Samiei, 2012).

Therefore, it is rational to identify how eWOM occurs on the Facebook platform in a highly mobile data-driven country like Sri Lanka while further studying its influence on PI, with a mediating role of Brand Image. Hence this research will be a unique study in the island's mobile-telecommunication industry in a mobile broadband silo. Thus, eWOM is evident to study as an independent variable affecting Purchase Intension as a Dependable Variable (Tariq et al., 2017). Further, eWOM can be narrowed on the context of Facebook while more focusing on Facebook inherent types of eWOM activities such as reading or perusing Likes, Comments \& Shares (Richard \& Guppy, 2014) while 
understanding the moderating role of Brand Image (Tariq et al., 2007), further this moderation has prejustified in an empirical study in the automobile industry in Iran (Jalilvand \& Samiei, 2012) hence it is logical to study the eWOM \& Purchase Intention further. The intermediation of Brand Image will give a clear perspective on this topic area with clear managerial and scholarly need-of-time.

A key focus of this research was to study further how to make eWOM impacts purchase Intention towards mobile data packages in Sri Lanka with a further analysis of the mediation of brand image with a particular reference to the Facebook users.

\section{CONCEPTUAL FRAMEWORK}

According to Jalilvand \& Samiei (2012), the below framework, depicted in figure 2 below, has tested to study the effect of eWOM as Independent Variable on Brand Image (in mediation) and Purchase Intention as a dependable variable resulting as eWOM has a considerable effect on Brand Image \& a direct effect on Purchase Intention when tested on automobile industry in Turkey. Even though the model showed a significant relationship between eWOM and Purchase Intention, this framework was not tailor-made to test the same behaviour on the Facebook platform as it is the specific sample audience which narrowed by the researcher to study closer about the mobile data users in Sri Lanka and their movement on Facebook a similar vital platform in the country to be studied over the topic of electronicword-of-mouth. Hence, the researcher further studied to find a more context-friendly model which precisely elaborates eWOM constructs tailor-made for the Facebook platform.

The conceptual model tested by Richard \& Guppy (2014) further narrowed the eWOM factor to Facebook, which elicits through Likes, Friend Likes, Location-based check-in, Comments and Shares in the Independent Variable scope over the Dependable Variable of Purchas Intention, here they have tested 216 Facebook users \& given a link via Facebook itself to answer a questionnaire and data were collected over three weeks period in August 2012. The findings were impressive such as the 'Friends Like' sub construct of the independent variable were most impactful on Purchase Intention followed by Check-In, Page Likes, and Sharing. These findings are further justified by a study conducted by Harris \& Dennis (2011), who indicated that consumers trust friends \& family over Products and services. Thus the researcher derived the proposed conceptual framework (Figure 2) in a hybrid of Jalilvand \& Semiei (2012) model, which surrounds eWOM on Purchase Intention \& Brand Image, and the YouTube platform-specific model derived by Richard \& Guppy (2014) to investigate the influence of Facebook: with a microscopic view of the eWOM hemispherical components such as Likes \& Comments on Consumer's purchase intention but left out the construct: FB-checked-in component to create clarity to independent variables which already has four sub-constructs and considered the most common Facebook activities that are the Product Likes, Friends Likes, Comment Postings and Sharing according to Statista (2018) and ubiquitous platform nature for YouTube too. Thus developed the hypothesis based on figure 2: Conceptual Framework. 
Figure 2: Proposed Conceptual Framework constructed by the author as a hybrid model derived from Jalilvand \& Samiei (2012) and Richard \& Guppy (2014)

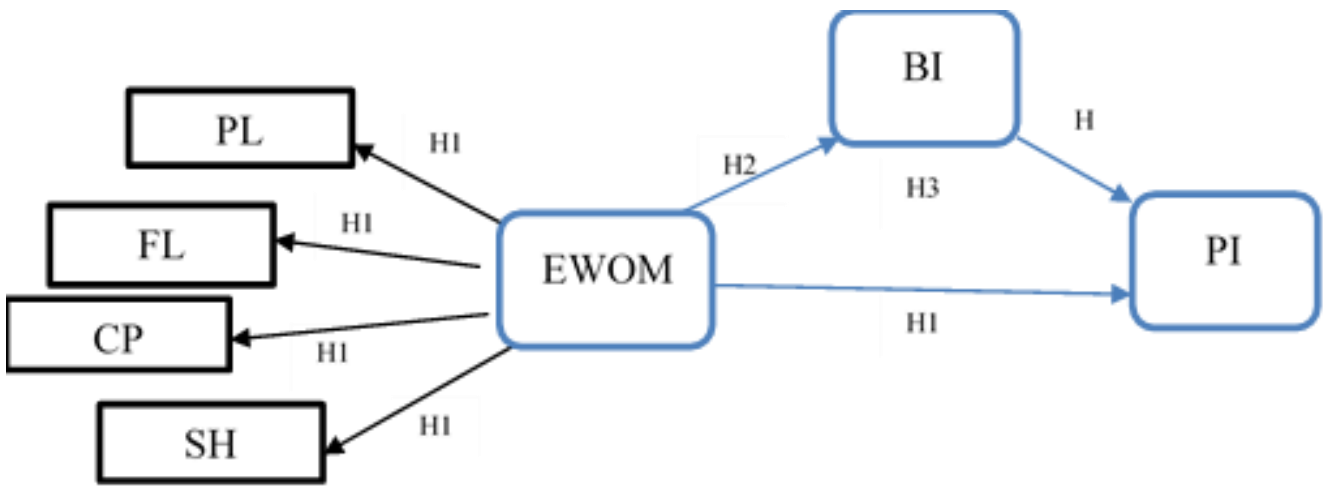

EWOM - electronic word of mouth

PI - Purchase Intention

FL- Friend's Likes

CP- Comment Postings

SH- Sharing

BI- Brand Image

\section{HYPOTHESES}

The primary purpose of the present study is to examine the relationship of eWOM and Purchase Intention of Mobile data packages among Facebook users when moderating with Brand Image. Therefore, have developed several hypotheses to demonstrate these relationships, as further elaborated below.

\subsection{Brand Image \& Purchase Intention}

Interpersonal influences $\&$ brand cues identified shaping purchase intentions, and Brand Image was a significant moderator (Shukla, 2010), as well as proof that the Brand Image affects consumer Purchase Intention (Lin, C. \& Chuang, S. 2018), and Brand Image identified as a mediator in the relation of eWOM \& PI (Jalilvand \& Samiei, 2012); therefore:

\section{H+: There is a positive relationship between Brand Image and Purchase Intention}

Thus, this hypothesis constructs the argument to test Brand Image's contribution to the Purchase Intention of the said consumer.

\section{2. eWOM \& Purchase Intention}

According to Jalilvand \& Samiei (2012), it has proven that eWOM has a substantial and direct effect on Purchase Intention in the automobile industry in Turkey, and Tariq et al. (2017) found the same 
relationship from research conducted for university students sample used mobile phones in Rawalpindi \& Islamabad. However, Torlak et al. (2014) could not find a significant relationship between eWOM and Purchase Intention for research conducted on Cell Phone Brands in Turkey. Hence it was vital to test such a relationship in a different context, such as mobile data users in Sri Lanka. Therefore:

H1+: There is a positive relationship between eWOM and Purchase Intention

Hence, it creates a hypothetical view for examining the relationship of eWOM and Purchase Intention, the nucleus of this research.

\subsection{Product Likes}

The 'LIKE' application in the FB allows the user to share pages on their FB profiles (Harris \& Dennis, 2011), once 'Liked' a page fan receives updates (Nelson-Field et al., 2012) which consists of newproduct advertisements, discounts, recommendations by others; therefore, Friend Likes:

H1a+: There is a positive relationship between the Product Likes and Brand Image.

The information derived from 'friends' is trustworthy \& the consumer tends to purchase products recommended by their friends (Richard \& Guppy, 2014); therefore, Comment postings:

$\mathrm{H} 1 \mathrm{~b}+:$ There has a positive relationship between the Friends Likes and Brand Image.

On the other hand, Facebook users can see the displayed comments given by their friends in real-time via the newsfeed (Debatin et al., 2009). As customers' opinions on goods $\&$ services with a multitude of other customers (Henning -Thurau et al., 2004) can thus influence purchase decision, and it is not widely researched (Richard \& Guppy, 2014); therefore, Facebook Sharing

$\mathrm{H} 1 \mathrm{c}+$ : has a positive relationship between the Comment Posting and Brand Image. Further, explain as one million links are shared per 20 minutes on FB (Branckaute, 2010), which is an enormous flow of eWOM worthy Facebook content; therefore:

H1d+: There is a positive relationship between the Facebook Sharing and Brand Image.

\section{4. eWOM \& Brand Image}

Jalilvand \& Samiei (2021) pointed out a robust impact of electronic-word-of-mouth on Brand Image, further proven by Tariq et al. (2017) on a sample of mobile users; therefore

H2+: There is a positive relationship between eWOM and Brand Image 


\section{METHODOLOGY}

This research problem was developed on the previous studies done on the relationship of eWOM and Purchase Intention. This research problem was justified by literature and further clearly emerged from the literature and practice gaps.

Primary Data collection was instrumental under Qualitative research with an in-depth interview to gather Exploratory research information, and Secondary Data was collected through Published journals, Reports, Annual Reports \& Websites. Under the Quantitative Research, a Survey was planned to use as the Data collecting method and use a Questionnaire (attached in the annexure) as an instrument to collect data employed by 5-point Likert scale with $1=$ Never $\& 5=$ Always and unit of analysis was 'mobile data usage.' The sample size is dented as 267 with a mix of male \& female FB users from the age 18 to $65+$ categories, assuming that most of them are young users. The Independent Variable: Product Likes, Friend's Likes, Page Comments \& Sharing constructs were measured for attention, use, and interest were derived from Ko, Cho \& Roberts (2005) Richard \& Guppy (2014) and comment postings sub-variable measurement derived from Bambauer-Sachse \& Mangold (2011). The Mediating Variable: Brand Image derived from Davis et al. (2009) and the Dependent Variable: Purchase Intention derived from Richard \& Guppy (2014) and Shukla (2010).

The aforesaid in-depth interview with a Sugunasekera, A. (2018) was conducted to lay exploratory research as a foundation for further research on the Mobile data packages and found out Facebook is one of the leading platforms; in other words, one of the main data-burners in the mobile telco industry.

Thus, the sample profile predominantly screened for the Facebook user category versus a mere data user because the core research objective was to examine the Facebook user behaviour over eWOM and Purchase Intension.

\section{RESULTS AND DISCUSSION}

It tested to identify the variables selected for the study - Product Likes, Friends Likes, Comments Posting, and Facebook Sharing by hypothesizing have a positive relationship on Purchase Intention of Mobile data packages while Brand Image mediating the relationship in a positive stance and further elaborated via the below data analysis. According to the analysis, all the latent variables received Cronbach's Alpha $>0.7$ for reliability and test for validity $>0.5$; hence the condition is fulfilled through the analysis, the data is considered to have validity. All the independent variables were statistically significant in the relationship between the dependent variable - Purchase Intention - and mediating variable - Brand Image. Brand Image also has a statistically highly significant relationship between purchase intentions of Mobile data packages among Facebook users in Sri Lanka in the considered 
sample. Structural equation modeling (SEM) is a methodology for representing, estimating, and testing a relationship between variables. Analyzing data and interpreting results can be complex and confusing in the traditional statistical approaches. Hence, employing this modeling was able thus to depict the relationships between variables.

Figure 1: PLS full model

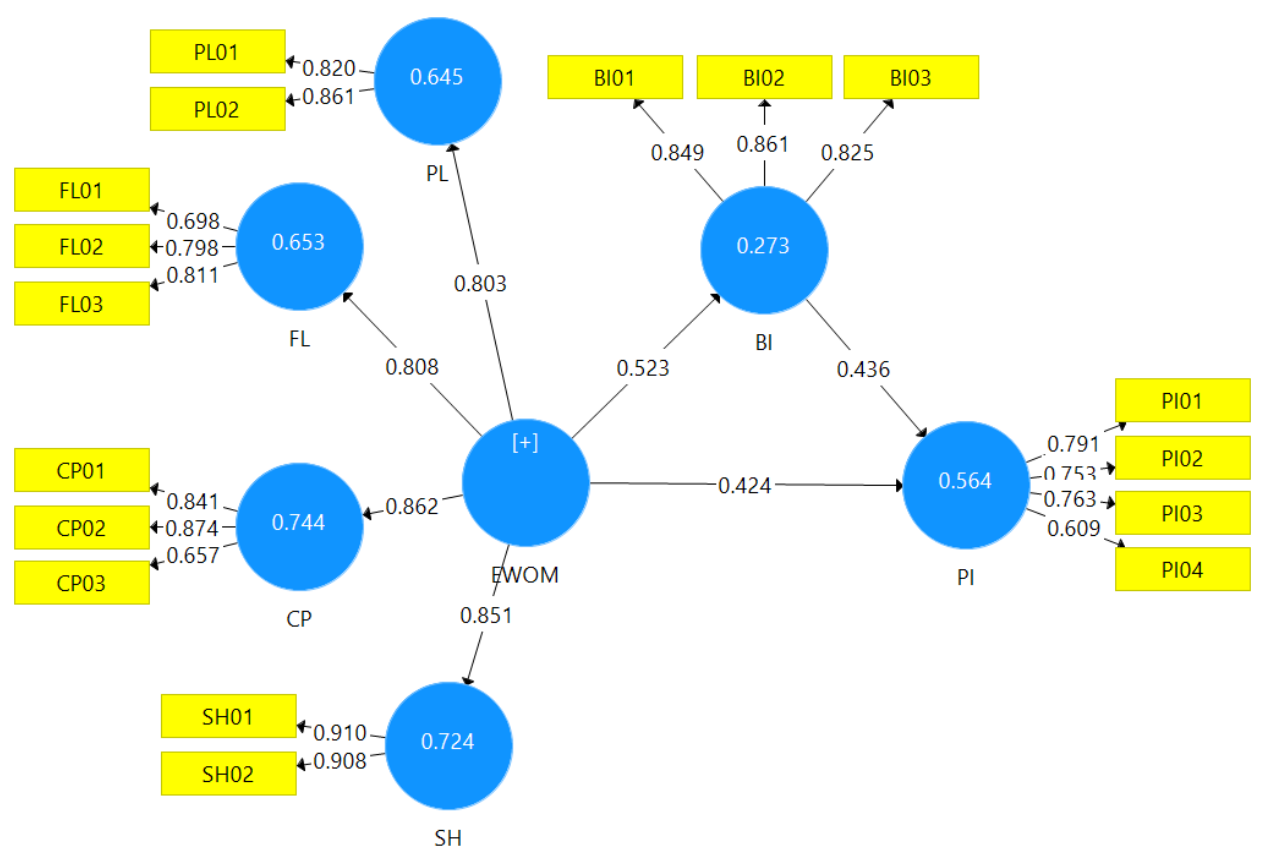

The individual path coefficients in the structural model and the table represents the standardized beta coefficients $(\boldsymbol{\beta})$ in an OLS regression which express a one-unit change of the exogenous construct changes the endogenous construct by the size of the path coefficient while everything remains constant. According to the findings, all the path coefficients in the structural model are significantly based on all the criteria. Accordingly, in all the 07 cases, both $\mathbf{t}$ and $\mathbf{p}$ values are achieved at the threshold levels $(\mathrm{p}<0.05,-1.96 \mathrm{t}<+1.96)$ as per the other criterion. That means, if confidence intervals of bootstrapping BCA values do not include zero, path coefficients are significant. This requirement is fulfilled in the path coefficient of all the variables. Therefore, all other path coefficients are statistically significant under both criteria. The highest path coefficient $(\beta=0.862)$ was reported in the path of CP towards EWOM. That means when the CP increases by one unit, EWOM will be positively changed by 0.862 units. As the second-highest path coefficient $(\beta=0.851)$, SH has a significant impact on EWOM. Further, EWOM is showing a significant positive relationship with PI. Moreover, the EWOM level and BI also play significant relationships.

The path coefficient represents the exogenous latent variables' combined effect on the endogenous latent variable (Ringle et al., 2018; Kumari, Ferdous Azam \& Siti Khalida. 2020) . In the next step, the researchers should assess the R2 values of all the endogenous constructs to measure the model's in- 
sample predictive power. According to Hair et al. (2017), when R2 values become 0.25, 0.50, and 0.75, it implied that the respective endogenous variables are weak, moderate, and strong, respectively. Therefore, one of the main parts of the structural model evaluation is the assessment of the coefficient of determination $\left(\mathbf{R}^{2}\right)$. In the present research, Purchase Intention (PI) is the central construct of interest (dependent variable). As per the estimated structural model given in figure 1 , the overall $\mathrm{R}^{2}$ is 0.564 , found to be a moderate level. In this case, it suggests that the three constructs, i.e., EWOM, BI, and PI, can jointly explain $56.4 \%$ of the variance of the endogenous construct (Purchase Intention). The $\mathrm{R}^{2}$ value is 0.564 ; it is shown inside the blue circle of the PI construct in the PLS diagram (see Figure 1).

Table 1: Output of PLS full model

\begin{tabular}{|c|c|c|c|c|c|c|c|}
\hline & $\begin{array}{c}\text { Original } \\
\text { Sample } \\
(\beta)\end{array}$ & $\begin{array}{c}\text { Sample } \\
\text { Mean (M) }\end{array}$ & $\begin{array}{c}\text { Standard } \\
\text { Deviation } \\
\text { (STDEV) }\end{array}$ & $\begin{array}{c}\text { T-Statistics } \\
(|\mathrm{O} / \mathrm{STDEV}|)\end{array}$ & P-Values & $2.50 \%$ & $97.50 \%$ \\
\hline $\mathrm{BI} \rightarrow \mathrm{PI}$ & 0.436 & 0.435 & 0.057 & 7.706 & 0 & 0.323 & 0.542 \\
\hline EWOM $\rightarrow \mathrm{BI}$ & 0.523 & 0.523 & 0.059 & 8.84 & 0 & 0.398 & 0.63 \\
\hline EWOM $\rightarrow C P$ & 0.862 & 0.862 & 0.021 & 41.759 & 0 & 0.813 & 0.897 \\
\hline EWOM $\rightarrow \mathrm{FL}$ & 0.808 & 0.809 & 0.027 & 30.085 & 0 & 0.744 & 0.853 \\
\hline EWOM $>P \mathrm{PI}$ & 0.424 & 0.426 & 0.054 & 7.848 & 0 & 0.316 & 0.527 \\
\hline EWOM $\rightarrow P L$ & 0.803 & 0.804 & 0.024 & 33.834 & 0 & 0.746 & 0.843 \\
\hline EWOM $\rightarrow S H$ & 0.851 & 0.85 & 0.023 & 36.858 & 0 & 0.798 & 0.888 \\
\hline
\end{tabular}

\subsection{Direct Hypotheses H1}

Thus, empirically analysed the core focus of this research, the direct relationship of eWOM and Purchase Intention. It is depicted in Figure 3 and explained below.

Figure 3: Direct relationship between EWOM and PI

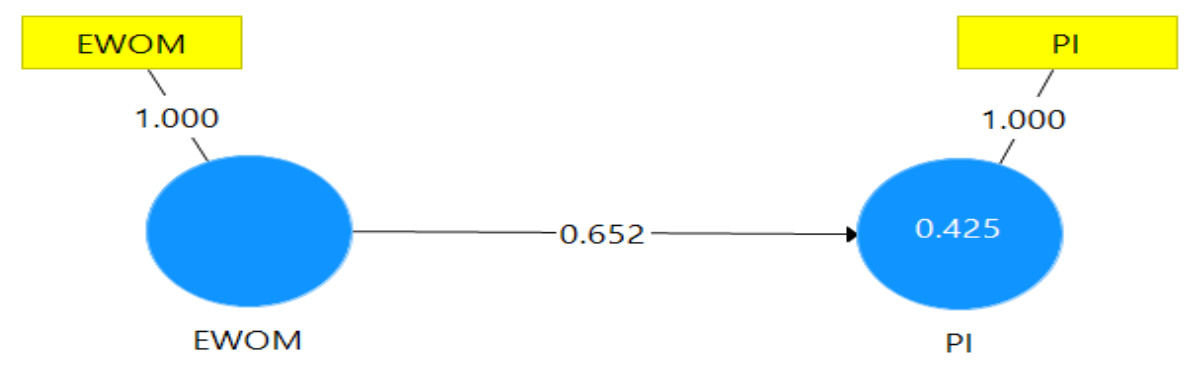

Table 2: Direct relationship between EWOM and PI

\begin{tabular}{|l|c|c|c|c|c|c|c|c|}
\hline & $\begin{array}{c}\text { Original } \\
\text { Sample } \\
(\boldsymbol{\beta})\end{array}$ & $\begin{array}{c}\text { Sample } \\
\text { Mean } \\
(\mathrm{M})\end{array}$ & $\begin{array}{c}\text { Standard } \\
\text { Deviation } \\
(\text { STDEV) }\end{array}$ & $\begin{array}{c}\text { T Statistics } \\
(\mid \text { O/STDEV|) }\end{array}$ & $\begin{array}{c}\mathrm{P} \\
\text { Values }\end{array}$ & $2.50 \%$ & $97.50 \%$ & $\begin{array}{c}\text { Hypothesis } \\
\text { Accept or } \\
\text { Reject }\end{array}$ \\
\hline $\begin{array}{l}\text { EWOM }- \\
>\mathrm{PI}\end{array}$ & 0.652 & 0.652 & 0.042 & 15.576 & 0 & 0.56 & 0.724 & H1 Accepted \\
\hline
\end{tabular}


The study's main objective is to investigate the influence made by EWOM towards the consumer Purchase intention (PI) of mobile data packages in Sri Lanka. The first hypothesis (Direct effect) was developed to support the above objective. Figure 3 display the direct effect of the model after executing the SmartPLS 3 algorithm.

The standardized beta value of the relationship is 0.652 , where one unit change in the EWOM, the PI will be changed by 0.652 units. Moreover, the $t$ value is 15.576 , which is more than the recommended value of 1.96. The relationship of the EWOM towards the PI is positive and significant at the level of 0.05. Further, the confidence interval of the path coefficient $(\mathrm{BCa})$ is significantly different from zero. Since all the criteria were satisfied, therefore, hypothesis H1 is accepted. Hence, the researcher can conclude that EWOM positively and significantly relates to the PI.

\subsection{Four Dimensions of eWOM}

In addition to testing the direct relationship of EWOM on PI, the researcher needed to identify the most significant dimension of EWOM out of four dimensions. According to the PLS model, those subhypotheses were tested by using path coefficients (standardized beta coefficients), probability values ( $p$-value), t statistics ( $\mathrm{t}$ value), Bias-corrected and accelerated (BCa) bootstrap confidence intervals, and $\mathrm{R}^{2}$ values considering specified threshold levels and results were shown in figure $4 \&$ table 3 .

Figure 4: Dimensional Relationship of EWOM

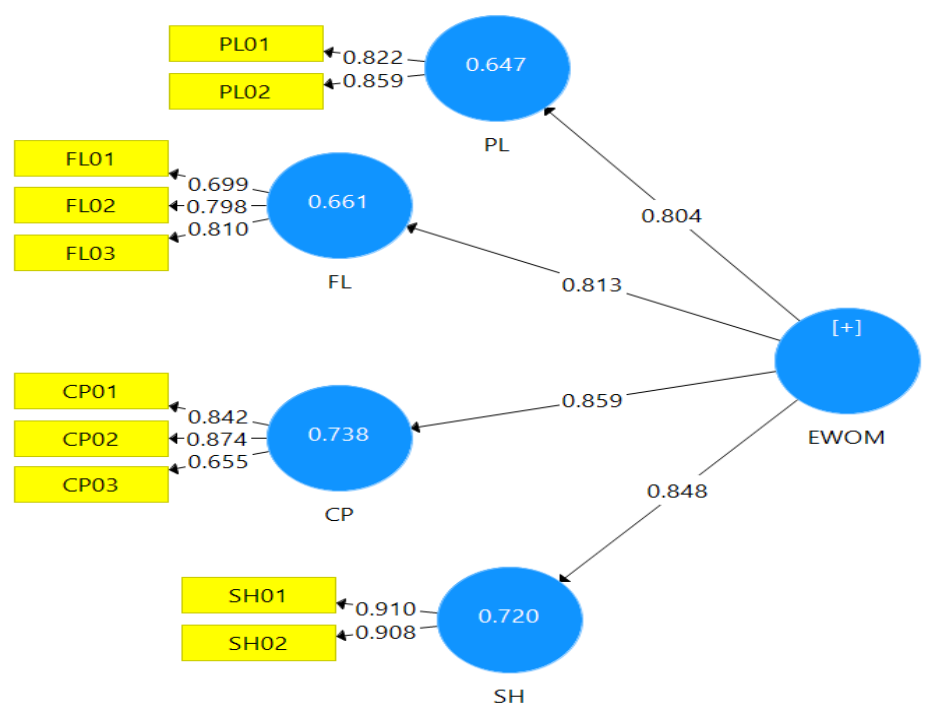


Table 3: Dimensional Relationship of EWOM

\begin{tabular}{|c|c|c|c|c|c|c|c|c|}
\hline & $\begin{array}{c}\text { Original } \\
\text { Sample } \\
(\beta)\end{array}$ & $\begin{array}{c}\text { Sample } \\
\text { Mean } \\
\text { (M) }\end{array}$ & $\begin{array}{c}\text { Standard } \\
\text { Deviation } \\
\text { (STDEV) }\end{array}$ & $\begin{array}{c}\text { T Statistics } \\
(\mid \mathrm{O} / \text { STDEV } \mid)\end{array}$ & P Values & $2.50 \%$ & $97.50 \%$ & $\begin{array}{c}\text { Hypothesis } \\
\text { Accept or } \\
\text { Reject }\end{array}$ \\
\hline $\begin{array}{ll}\text { EWOM } \quad-> \\
\mathrm{CP}\end{array}$ & 0.859 & 0.859 & 0.02 & 42.027 & 0 & 0.809 & 0.892 & $\begin{array}{l}\mathrm{H} 1 \mathrm{a} \\
\text { Accepted }\end{array}$ \\
\hline $\begin{array}{ll}\text { EWOM } \rightarrow \\
\text { FL }\end{array}$ & 0.813 & 0.813 & 0.027 & 30.478 & 0 & 0.752 & 0.858 & $\begin{array}{l}\text { H1b } \\
\text { Accepted }\end{array}$ \\
\hline $\begin{array}{ll}\text { EWOM } \rightarrow \\
\mathrm{PL}\end{array}$ & 0.804 & 0.806 & 0.024 & 33.58 & 0 & 0.751 & 0.845 & $\begin{array}{l}\text { H1c } \\
\text { Accepted }\end{array}$ \\
\hline $\begin{array}{ll}\text { EWOM } \quad-> \\
\text { SH }\end{array}$ & 0.848 & 0.848 & 0.024 & 35.558 & 0 & 0.792 & 0.886 & $\begin{array}{l}\text { H1d } \\
\text { Accepted }\end{array}$ \\
\hline
\end{tabular}

According to the above table 3. the standard beta $(\boldsymbol{\beta})$ values of all the sub-variables (PL, FI, CP, and $\mathrm{SH})$ were positive, and the highest stranded beta value was observed in CP (0.859), followed by SH (0.848), FL (0.813), and PL (0.804). The lowest std. Beta value was observed in PL (0.804). $\mathbf{t}$ values of each 04-sub variable show the positive and higher threshold value of 1.96. The p-value of each variable is positive and significant at the 0.00 level. Moreover, the confidence intervals of each sub-variables were significantly different from zero. Therefore, sub- hypotheses H1a, H1b, H1c, H1d are accepted. Hence, the researcher can confirm that all the sub-variables have a positive and significant relationship to the EWOMR in Sri Lanka mobile data packages.

\subsection{Mediation Hypotheses $\mathrm{H3}$}

Figure 5: Mediation impact of BI on the relationship between EWOM and PI

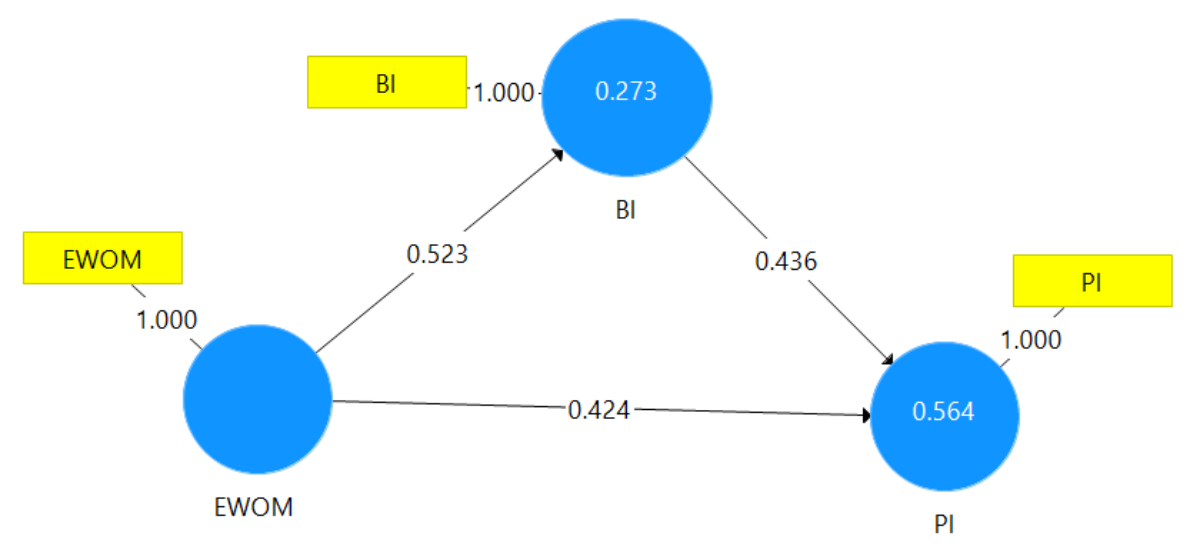

Table 4: Mediation impact of BI on the relationship between EWOM and PI

\begin{tabular}{|c|c|c|c|c|c|c|c|c|}
\hline & $\begin{array}{l}\text { Original } \\
\text { Sample } \\
\text { (B) } \\
\end{array}$ & $\begin{array}{l}\text { Sample } \\
\text { Mean } \\
\text { (M) } \\
\end{array}$ & $\begin{array}{l}\text { Standard } \\
\text { Deviation } \\
\text { (STDEV) }\end{array}$ & $\begin{array}{l}\text { T Statistics } \\
(|\mathrm{O} / \mathrm{STDEV}|)\end{array}$ & $\begin{array}{l}\mathrm{P} \\
\text { Values }\end{array}$ & $2.50 \%$ & $97.50 \%$ & \\
\hline $\mathrm{BI}->\mathrm{PI}$ & 0.436 & 0.433 & 0.055 & 7.957 & 0 & 0.329 & 0.541 & $\mathrm{H} 4$ \\
\hline $\begin{array}{ll}\text { EWOM } & \rightarrow> \\
\mathrm{BI} & \\
\end{array}$ & 0.523 & 0.52 & 0.058 & 8.977 & 0 & 0.397 & 0.627 & $\mathrm{H} 2$ \\
\hline $\begin{array}{ll}\text { EWOM } & -> \\
\text { PI } & \\
\end{array}$ & 0.424 & 0.426 & 0.051 & 8.373 & 0 & 0.324 & 0.524 & \\
\hline
\end{tabular}


In testing the mediating role of $\mathrm{BI}$, the below hypothesis was developed to achieve the specific objective, which is to analyze the mediating impact of BI on the relationship between EWOM and PI. The researcher has developed the below hypotheses based on the literature review to align with the above objective. These hypotheses were,

- H2: There is a positive relationship between the EWOM and Brand Image (BI)

- H3: Brand Image (BI) is indirectly, partially, and positively mediated by the association of EWOM and Purchase Intention (PI)

- H4: There is a positive relationship between the Brand Image (BI) and Purchase Intention (PI)

According to the above table 4. the standard beta values of all the two variables (EWOM> BI) and $\mathrm{BI}>\mathrm{PI}$ ) were positive, and the highest stranded beta value was observed. $\mathrm{T}$ values of each variable showed a positive and higher threshold value of 1.96 . The $\mathbf{p}$-value of each variable is positive and significant at 0.05 level. Moreover, the confidence intervals of each sub-variable were significantly different from zero. Therefore, hypotheses $\mathrm{H} 2$ and $\mathrm{H} 4$ are accepted. Hence, the researcher can have confirmed that two main hypotheses were accepted. In the current context, to analyze the mediating role of the BI, the researcher had used the comparison of direct effect (EWOM > PI) and indirect effect (EWOM $>$ BI $>$ PI). Figure 5 and Table 4 depict the direct and indirect effects followed by the standard $\beta$ results.

As suggested by Hair et al. (2017), to get the understanding of the mediation role researcher must consolidate both path coefficients of direct and indirect effects. Below table 5. display the significance analysis of the direct and indirect effects.

According to the results, the direct effect of EWOM on PI has been significantly dropped as the respective path coefficient was reduced from 0.652 (see figure 3 and table 2) to 0.424 . Therefore, the magnitude of the effect is $0.128(0.652-0.424)$, equal to the Product of coefficient $(0.523 * 0.436)$. Further, the bootstrapping t-test results are shown in table 5. noting that the direct path is less significant after introducing the mediating variable. Hence, the mediation effect is identified based on the specifications given by Judd and Kenny (1981) and Preacher and Hayes (2008). Results in table 5. explained that the BI mediates the relationship between EWOM with PI was empirically supported in the present research context. Accordingly, intense mediation is detected. Therefore, hypothesis $\mathbf{H 3}$ is accepted. 
Table 5: A mediation analysis of Direct and Indirect effects

\begin{tabular}{|c|c|c|c|c|c|c|c|c|}
\hline Path & $\begin{array}{l}\text { Direct } \\
\text { Effect }\end{array}$ & $\begin{array}{c}95 \% \\
\text { Confidence } \\
\text { interval of the } \\
\text { Direct Effect }\end{array}$ & $\begin{array}{c}\mathrm{t}- \\
\text { value }\end{array}$ & $\begin{array}{c}\text { Signi } \\
(p<0.05)\end{array}$ & $\begin{array}{c}\text { Indirect } \\
\text { Effect }\end{array}$ & $\begin{array}{c}95 \% \\
\text { Confidence } \\
\text { interval of } \\
\text { the Indirect } \\
\text { Effect }\end{array}$ & $\mathrm{t}$-value & $\begin{array}{c}\text { Signi } \\
(p<0.05)\end{array}$ \\
\hline $\begin{array}{l}\text { EWOM - } \\
>\mathrm{PI}\end{array}$ & 0.652 & $0.56-0.724$ & 15.576 & $\begin{array}{l}0.000 \\
\text { (Yes) }\end{array}$ & 0.424 & $0.324-0.524$ & 8.373 & $\begin{array}{l}0.000 \\
\text { (Yes) }\end{array}$ \\
\hline
\end{tabular}

Source: Author developed based on the SmartPLS bootstrap results

\section{CONCLUSION}

With a rigorous statistical analysis of data collected, it was identified that there is a positive relationship between eWOM and Purchase Intention for Mobile data packages in the context of Facebook users of Sri Lanka. Further, the relationship was positively strengthened by Brand Image as a mediating variable. Furthermore, no proper theoretical evidence was found in the literature review on eWOM on Purchase Intention with an intermediary variable as Brand Image uniquely done for the mobile telecommunication sector related to mobile data packages or Facebook users. Therefore, this research provides tested results for both practitioners and scholars in understanding eWOM behaviour on Purchase Intention in Sri Lankan Facebook users' context. This outcome further proves the researchers conducted by Jalilvand \& Samiei (2012) \& Richard \& Guppy (2014) eWOM.

These research findings will open very crucial managerial implications when generating content for social media on the Facebook platform where, thus proven that eWOM has a positive impact on Purchase Intension, which means that employing a more scientific approach in content creation can lead to producing more successful contents which has virality DNAs, eventually cascades to electronic wordof-mouth. Furthermore, the eWOM ultimately translates to Purchase Intention, i.e., impacting the profitability. Hence, this research points out the gravity and importance of eWOM having a direct business impact than a trendy concept.

Thus, future researchers can test this model to understand Brand Image mediation using in different contexts. Furthermore, this outcome could be used to take in the note as base research to test in different social networking sites such as Tik Tok or YouTube, perhaps could give different outcomes and new knowledge to the academic \& business world. 


\section{LIST OF REFERENCES}

Alexa ( 2018, May 7 ) https://www.alexa.com/topsites/countries/lk

Alfred, B. L. \& Biswas, A. (2002). The effects of discount level, price consciousness \& sales proponents on consumers' price perception \& behavioural Intention. Journal of Business, 55(9), pp. 775-783.

Anderson, E. W., 1998. Customer satisfaction and word of mouth. Journal of Service Research, 1(1), pp. 5-17.

Andreasen, W. T. \& Streukens, S. (2009). Service innovation \& electronic word of mouth: is it worth listening to? Managing service quality, 19(3), pp. 249-265.

Arndt, J. (1967). Role of Product related conversations in the diffusion of a new product. Journal of Marketing Research, Volume 4, pp. 291-295.

Bickart, B. \& Schindler, R. (2001). Internet forums as influential sources of consumer information. Journal of Interactive Marketing, Volume 15, pp. 31-40.

Boyd, D. M. \& Elision, N. B. (2007). Social network sites: definition, history \& scholarship. Journal of ComputerMediated Communication, 13(1), pp. 210-230.

Branckaute, F. (2010, Feb 19) Facebook Statistics: The numbers game continues.

http://www.blogherald.com/2010/08/11/facebook-statistics-the-numbers-game-continues/

Burman, C., Schaefer, K. \& Maloney, P. (2008). Industry image: its impact on the brand image of potential employees. Journal of Brand Management, 16(3), pp. 159-176.

Chan, Y. Y. \& Ngai, E. (2011). Conceptualizing electronic word of mouth activity: An input - process - output perspective. Marketing Intelligence \& Planning, 29(5), pp. 488-516.

Cheung, C. M. K., Lee, M. K. O. \& Rabjohn, N. (2008). The impact of eWOM. Internet Research, 18(3), p. 229.

Cheung, C. M. K. \& Thadani, D. R. (2010). The effectiveness of eWOM communication: a literature analysis, Bled, s.n.

Ching, R. K., Tong, P., Chen, J.-S. \& Chen, H.-Y. (2013). Narrative Online Advertising: Identification and its Effects on Attitude Toward a Product. Internet Research, 23(4), pp. 414-438.

Chovancova, M., Asamoah, E. S., Wanninayake, W.M.C.B (2012), Consumer Behaviour and Branding: A cross Cultural Perspectives, GEORG Zilina, Bojzova11, 01001, Zilina, Slovak Republic.

Debatin, B., Lovejoy, J. P., Horn, A. K. \& Hughes. (n.d.) Facebook \& online privacy: Attitudes, behaviours \& unintended consequences. Journal of Computer-Mediated Communication, 15(1), pp. 83-108.

DELL Worldwide (2018, Feb 23 ). The impact of social media on purchasing behaviour, engaging consumers online. [Online] Available at: http://www.deiworldwide.com/files/DEIStudy\%20ConsumersOnline-Summery.pdf

Dialog Axiata PLC (2016). The Annual Report, Colombo: Dialog Axiata PLC.

Digital marketer.lk (2016, May 15). Internet usage statistics in Sri Lanka. [Online] Available at: http://www.digitalmarketer.lk/internet-usage-statistics-in-sri-lanka.html 
Dunham, B. (2011). The role of signalling theory and receiver psychology in marketing. In evolutionary psychology in the business sciences. In: s.1.: Springer Berlin Heidelberg, pp. 225-256.

Dwyer, C., Hiltz, S. R. \& Passerini, K. (2007). Trust and privacy concern within social media networking sites: a comparison of Facebook and MySpace. s.l., s.n.

Gogoi, B. (2013). Study of antecedents of purchase intention and the effect on brand loyalty of private label brand of apparel. International Journal of Sales \& Marketing, 3(2), pp. 73-86.

Gruen, T. W., Osmonbekov, T. \& Czaplewski, A. J. (2006). EWOM the impact of the customer-to-customer online know-how exchange on customer value and loyalty. Journal of Business Research, 59(4), pp. 449-456.

Harris, L. \& Dennis, C. (2011). Engaging customers on Facebook: challenges for e-retailers. Journal of Consumer Behaviour, 10(6), pp. 338-346.

Harrison- Walker, L. J. (2001). The measurement of WOM communications and an investigation of service quality and customer commitment as potential antecedents. Journal of service research, Volume 4, pp. 60-75.

Henning-Thurau, T., Gwinner, K. P., Walsh, G. \& Gremler, D. D. (2004). Electronic word of mouth via consumer opinion platforms: what motivates consumers to articulate themselves on the Internet? Journal of Interactive Marketing, 18(1), pp. 38-52.

Hootsuite (2018, February 10). Digital Report on Sri Lanka. [Online] Available at: www.hootsuite.com [Accessed 10 February 2018].

Hung, K. H. \& Li, S. Y. (2007). The influence of eWOM on virtual consumer communities: social capital, consumer learning \& behavioural outcomes. Journal of Advertising Research, 47(4), p. 485.

Indexmundai, 2018. Sri Lanka. https://www.indexmundi.com/sri_lanka/

Internetlivestats (2016, May 15). Internet Live Stats. http://www.internetlivestats.com/

ITU (2018, February 2). ICT Development Index 2017.http://www.itu.com

Jalilvand, R. M. \& Samiei, N. (2012). The effect of eWOM on brand image and purchase intention: An empirical study in the automobile industry in Iran. Marketing Intelligence \& Planning, 30(4), pp. 406-476.

Jalilvand, M. R., Esfahani, S. S. \& Samiei, N. (2010). Electronic word of mouth: challenges \& opportunities, s.l.: Elsevier.

Keller, K. L. (1993). Conceptualizing, measuring, and managing customer-based brand equity. Journal of Marketing, Issue 57, pp. 1-22.

Ko, H., Cho, C. H. \& Roberts, M. S. (2005). Internet uses \& gratifications: A structural equation model of interactive advertising. Journal of Advertising, 34(2), pp. 57-70.

Kumari D.A.T. (2020). The Impact of Financial Literacy on Investment Decisions: With Special Reference to Undergraduates in Western Province, Sri Lanka. Asian Journal of Contemporary Education, Vol. 4, No. 2, 110126.

Kumari D.A.T., Ferdous Azam S. M. \& Siti Khalida. (2020). The Impact of Financial Literacy on Women's Economic Empowerment in Developing Countries: A Study Among the Rural Poor Women in Sri Lanka. Journal of Asian Social Science; Vol. 16, No. 2, ISSN 1911-2017 E-ISSN 1911-2025.Published by Canadian Canter of Science and Education. 
Kumari D.A.T (2013), "Factors Influencing the Adoption of Internet Banking: An empirical study in the context of commercial banks in Sri Lanka”. Sri Lanka Journal of Banking and Finance, Vol.1(2), pp 78-90.

Kumari D.A.T (2017).Financial Literacy: An Essential Tool for Empowerment of Women through Financial Inclusion-Literature Review.Equality and Management, 2017

Lee, J. \& Lee, J. N. (2009). Understanding the product information inference process in eWOM: An objectivity subjectivity dichotomy perspective. Information \& Management, 46(5), p. 302.

Lee, J., Park, D. \& Han, I. (2008). The effect of negative online consumer reviews on product attitude: An information processing view. Electronic Commerce Research \& Application, 7(3), p. 341.

Lifewire (2018, March 3). What is Facebook? https://www.lifewire.com/what-is-facebook-3486391

Lin, C. \& Chuang, S. (2018). The Importance of Brand Image on Consumer Purchase Attitude: A Case Study of ECommerce in Taiwan. Studies in Business and Economics. 13. 91-104. 10.2478/sbe-2018-0037.

Malhotra, N. K. (2007). Marketing Research: An Applied Orientation. 5th Edition ed. Noida: Dorling Kindersley (India) Pvt. Ltd. Licensees of Pearson Education in South Asia.

Miles, M. B., Huberman, A. M. \& Saldaña, J. (2014). Qualitative data analysis: A methods sourcebook. 3rd ed. California: SAGE.

NDBSecurities (2016, February 2). The Telecommunication Sector. http://ndbsecurties.com /DOC_PATH=/opt/downloads/Research/3/2016-07-21_17_19_23.pdf

NDB Securities (2016, February 2). The Telecommunication Sector: Rapid migration to mobile internet underway. http://www.ndbs.lk/pages/research_library/download_pdf.jsp

Nielsen (2018, February 12). Sri Lanka 2016 Review.https://lmd.lk/wp-content/uploads/2017/02/Nielsen-Sri-Lanka2016-Review.pdf

Park, D. H. \& Lee, J. (2008). eWOM overload and its effect on consumer behavioural intention depending on consumer involvement. Electronic Commerce Research Applications, 7(4), p. 386.

Ratnayake, S., Chang, L. \& Bimanee, M. (2006, February 10). Sri Lanka Telecom is the communication powerhouse. http://www.slt.lk/data/investor/pdf /lanka_securities_report.pdf

Richard, J. \& Guppy, S. (2014). Facebook: Investigating the influence on consumer purchase intention. Asian Journal of Business Research, 4(2).

Roy, D. \& Banerjee, S. (2007). Caring strategy for integration of brand identity with brand image. International journal of commerce and Management, 17(1/2), pp. 140-148.

Saunders, M., Lewis, P. \& Thornhill, A. (2009). Research Methods for Business Students. 5th Edition ed. Noida: Dorling Kindersley (India) Pvt. Ltd., Licensees of Pearson Education in South Asia.

Schiffman, L. G. \& Kanuk, L. L. (2010). Consumer Behaviour. New Jersey: Pearson-Prentice Hall.

Shukla, P., 2010. Impact of interpersonal influences, brand origin and brand image on luxury purchase intentions: Measuring inter-functional interactions \& cross-national comparison. Journal of World Business, 64(2). 
Soares, A. M. \& Pinho, J. C. (2014). Advertising in Online Social Networks: The Role of Perceived Enjoyment and Social Influence. Journal of Research in Interactive, 8(3), pp. 245-263.

SocialBakers (2018, February 28). Sri Lankan Facebook page statistics. https://www.socialbakers.com/statistics/facebook/pages/total/sri-lanka/

Sugunasekera, A. (2018). Interview on mobile data packages \& eWOM. [Sound Recording].

Survey Systems, 2018. Surveys. httt://www.surveysystems.com

Tariq, M., Abbas, T., Abrar, M. \& Iqbal, A. (2017). Brand awareness impact on consumer purchase intension: the mediating role of brand image. Pakistan Administrative Review, 1(1).

The Central Bank (2016). The Annual Report, s.l.: s.n.

The World Bank (2018, March 4). World Bank in Sri Lanka. http://www.worldbank.org/en/country/srilanka

Torlak, O., Ozkara, B. Y., Tiltay, M. A. \& Cengiz, H. (2014). The effect of eWOM on brand image and purchase intention: an approach concerning cell phone brands for youth consumers in Turkey. Journal of marketing development \& competitiveness, 8(2).

Tsimonis, G. \& Dimitriadis, S. (2014). Brand Strategies in social media. Marketing Intelligence \& Planning, 32(3), pp. 328-344.

Wanninayake, W.M.C.B, and M. Chovancova (2012). Store Personality and Behavioral Intentions of Customers: a Comparative Study of Retail Industry in the Czech Republic and Sri Lanka. ACTA Universitatis Agriculturae Et Silviculturae Mendelianae Brunensis, Czech Republic. Vol. LX (7), pp 477-484.

Wanninayake, W. M.C. B., \& Chovancová, M. (2012). Exploring the impact of consumer impulsiveness on cognitive dissonance: An empirical study of the University of Pardubice. Series de Faculty of Economics and Administration, 23(1), 160-171.

Yoo, B. \& Donthu, N. (2001). Developing and validating a multidimensional consumer-based brand equity scale. Journal of Business Research, 52(1), pp. 1-14.

Zikmund, W. G. (2018, March 4). Business Research Methods. http://www.swlearning.com/management/zikmund/bus_research/powerpoint/ch07.ppt 